\title{
Oil Consumption in 4WD Farm Tractors Used in Forestry Operations
}

\author{
Gianfranco Airoldi, Angela Calvo, Marco Manzone
}

\begin{abstract}
Farm tractors are still widely used in many forestry operations. Predicting fuel and lubricant costs is difficult because their consumption depends on a number of factors such as hours worked and operations performed. Fuel and lubricant consumption is important since it can have an impact at both the economic and environmental level. Many fuel models have been studied in the last decades, but few studies have focused on oil consumption. The ASABE (American Society of Agricultural and Biological Engineers) Standard suggested a model for predicting engine oil consumption of farm tractors of the 1980s, which are potentially different from modern tractor engines. In addition, the recent widespread application of semi-and fullpower-shift and continuous variable transmissions and the high number of hydraulic applications increased the amount of lubrication oil for transmission and hydraulic systems.

For these reasons, we analysed $1334 \mathrm{WD}$ recent model farm tractors used in forest operations with the aim to study:

engine, transmission and hydraulic system oil capacities

engine, transmission and hydraulic system oil change intervals as recommended by the manufacturers.

A new equation for engine oil consumption, as a function of the rated engine power, was first used and statistically analysed. It was similar to the equation developed by other authors (with a mean difference of $28 \%$, decreasing to $11 \%$ at the highest engine power), but well below the $A S A B E$ model (with an average engine oil consumption three times higher). Another equation of total oil consumption related to the rated engine power was then studied and compared with a recent study. The results showed an average displacement of $18 \%$, decreasing to $8 \%$ at the highest engine power. The differences, due to a different machine dataset (only $4 W D$ farm tractors that can be used for forestry operations were analysed) are, however, minimal also in the engine oil consumption model if compared with the oldest ones: a new proposal is therefore necessary, with new and affordable models for correctly evaluating economic and environmental forestry operation costs when using farm tractors.
\end{abstract}

Keywords: farm tractor, forest operations, engine oil consumption, total oil consumption, mechanisation cost, environmental cost

\section{Introduction}

Despite the use of custom built forestry machines, rubber-tyred farm tractors are still widely used in small-scale forestry in various sites (mountain areas, steep hills, urban forestry sites) and in non-industrial private forestry, where specialised forest-addressed machines may not be viable for the terrain morphology (Marchi et al. 2014, Spinelli and Magagnotti 2009, Spinelli et al. 2010) or for economic and environmental reasons (Spinelli and Magagnotti 2012, Šušnjar et al. 2008, Beuk et al. 2007). Rubber-tyred farm tractors with higher engine rated power are also commonly used in chipping and transport operations (Spinelli et al. 2005, Spinelli and Magagnotti 2014, Tolosana et al. 2011).

Although the mechanisation cost of these machines is lower than that of specialised forestry equipment, their owners are interested in the estimation of the operating costs (Bright 2004, Nordfjell et al. 2010, Röser et al. 2011, Spinelli and Magagnotti 2012, Gilanipoor et al. 2012). These costs are related to the use of the machine (Hawkins and Buckmaster 2015).

Fuel and lubricants are important cost items (Ackerman et al. 2017), but they are difficult to estimate because they depend on variable factors, such as hours 
worked, the operation performed, the type of fuel (Siemens and Bowers 1999) and the fuel and lubricant price, which have dramatically increased in the last 20 years (Hawkins and Buckmaster 2015). At the end of the 1990s, Siemens and Bowers found that the cost of fuel and lubricant for a farm tractor ranged between 16 and $45 \%$ of the total cost of the machine.

Fuel consumption prediction has been investigated by numerous authors since the 1970s (Fairbanks et al. 1971, Hunt 1974, Skrobacki 1989, Buckmaster 2003, Grisso et al. 2004, Klvač and Skoupý 2009, Guerrieri et al. 2016, Dahab et al. 2016). Some of them have developed forecast models for the fuel consumption of farm tractors, in accordance with the innovation in the engine design. For example, Grisso et al. (2008), after analysing the data of the Nebraska Tractor Test Laboratory (NTTL), studied new equations for predicting an improved tractor fuel consumption, stating the load and the engine speed reduction. These models were included in the ASABE Standard D497.7 (2011, Rev. 2015) and in the ASABE Standard EP 496.3 (2006).

However, limited studies have focused on oil consumption of farm tractors. Lubricant costs and consumption are lower than fuel costs, and according to Srivastava et al. (2006), the total cost of all lubricants in a farm tractor was approximately $10-15 \%$ of the fuel costs. On the other hand, lubricant is important for preserving the performance of the engine, pumps, bearings, gears, hydraulic systems and other parts of the tractor (Khodabakhshian 2013, Athanassiadis et al. 1999).

The correct preventative maintenance of the engine, transmission and hydraulic oil systems is a valuable operation and may later avoid critical repairs (Grisso and Pitman 2014).

Oil wear may vary as a function of the performed tasks: lighter operations cause less engine, transmission and hydraulic oil wear than more intensive use of the machine (Bekana et al. 2015). Good practice, however, consists of changing the oil in the engine and in the transmission-hydraulic systems as indicated by the manufacturer.

In 1958, Weber found that 39 farmers, among 59 surveyed in Illinois, never changed the transmission oil in their tractors. Some of them were aware of the manufacturers' recommendation, but preferred to take the risk, because it was an expensive and timeconsuming operation (Weber 1958). Witney (1988) analysed the engine oil consumption of engine power of some farm tractors, with the assumption that the oil is changed every 100 hours. Wertz et al. (1990) studied the engine oil service interval (the time of engine oil change) of 40 tractors in Nebraska farms and found that $58 \%$ of the farmers scheduled an engine oil service interval as indicated by the manufacturers (which was about $108 \mathrm{~h}$ ).

In a study conducted in southern Saudi Arabia, Wahby and Babeir (1994) found that about 70\% of farmers changed the engine oil close to the intervals suggested by the manufacturers, but only $23 \%$ of them controlled the transmission oil. Afsharnia et al. (2015) found that about $85 \%$ of the interviewed farmers in a province of Iran never scheduled an engine oil replacement using the manufacturer's recommendations.

Srivastava et al. (2006) used the equation of the ASAE Standard D497.4 (1999) to estimate the consumption of oil in gasoline, diesel and LPG engines. The model of the engine oil consumption stated by this ASAE Standard referred to a service interval of 100 hours (ASAE Standard EP496.2 1999), the same as stated by the former ASAE Standard EP391.1 (1984). It was difficult for the authors to determine a realistic value of the total oil consumption: the equation did not consider the replacement of the hydraulic and transmission oil systems or the topping-up between the oil changes (Srivastava et al. 2006).

The equation of the predicted engine oil consumption present in the ASAE Standard D497.4 was the same as that used in the previous versions of the ASAE Standard D497 series, called ASAE Standard D230.4 (1984). This equation is also present in the last version of the ASABE Standard D497.7 (2011, Rev. 2015).

During the last 34 years, however, farm tractors changed: the engine rated power increased, with a wide spread of power-shift and continuous variable transmissions (CVTs). Until recently, engine oil protected just the core element of the tractor from potential damages, the lubrication of the transmission system reduced its wear (avoiding sealing problems in the gaskets), and the hydraulic oil had the main function of conveying power and protecting the hydraulic tractor component. With the introduction of the modern CVTs, a further task of the transmission oil was to hydraulically transfer part of the engine torque to the drive shaft by a planetary gear (Molari et al. 2008).

At the same time, manufacturers reduced specific capacities of engine oil pans and increased the service interval between oil changes in the engine and in the transmissions and hydraulic systems. Tractor manufacturers developed more advanced machines to improve cost efficiency and to protect the environment, with low-emission diesel engines that require special long-life lubricants, increasing the engine oil service interval up to 500-700 hours. 
For these reasons, Calcante et al. (2017) developed a new equation for estimating engine oil consumption in farm tractors, using a database of 178 recently designed tractors of different types (2WD, 4WD and crawler). Their equation produced values $50 \%$ lower than the model proposed by the ASABE Standard D497.7, proving the necessity of an update in the calculation of engine oil consumption in farm tractors. The same authors, in another work (Calcante et al. 2019), estimated total lubricant oil consumption, analysing another sample of 255 recently designed farm tractors (2WD, 4WD and crawlers), with a power from 30 up to $375 \mathrm{~kW}$.

Using a different dataset and focusing on 4WD farm tractors that can also be used for forestry operations, this paper analysed the oil capacities of the engine and transmission plus hydraulic systems, as well as the recommended oil change intervals of 133 tractors of different models and/or manufacturers. The study concerned only rubber-tyred tractors. We also compared both the engine and the total oil consumption with the results found by Calcante et al. in 2017 and 2019, with the aim to evaluate possible differences when considering farm tractors for forestry operation purposes.

\section{Materials and Methods}

\subsection{Information Recorded}

The capacity of oil reservoirs and oil change intervals of the engine, transmission and hydraulic systems of 133 4WD farm tractors were analysed. The engine rated power (ERP) of the examined machines varied from 59 to $456 \mathrm{~kW}$. Data were collected from manufacturers' information and from reports of research institutes (the Swiss Centre Agroscope and the German DLG, Deutsche Landwirtschafts-Gesellschaft). The examined tractors were introduced into the market between 2011 and 2018.

For each tractor, the following data were recorded: $\operatorname{ERP}(\mathrm{kW})$, engine oil capacity $C_{\mathrm{E}}(\mathrm{l}$, litres), transmission oil capacity $C_{\mathrm{T}}(\mathrm{l})$, hydraulic oil capacity $C_{\mathrm{H}}(\mathrm{l})$, recommended change interval of engine oil $C I_{\mathrm{E}}$ (h, hours), recommended change interval of transmission oil $C_{\mathrm{T}}$ (h) and of hydraulic oil $C_{\mathrm{H}}(\mathrm{h})$. In some cases, the capacity of the transmission oil and hydraulic system and their change intervals were indicated as a unique number; for this reason, they were grouped together.

The oil consumption was obtained from the originally collected data, but the elaborations were carried out per 100 hours of machine work to avoid too many decimal numbers.

\subsection{Calculated Items}

The Specific Engine Oil Capacity (SEOCa) was calculated as the ratio between the engine oil capacity $C_{\mathrm{E}}$ and the engine rated power ERP (Eq. 1):

$$
S E O C a=\frac{C_{E}}{E R P}, \frac{1}{\mathrm{~kW}}
$$

Where:

SEOCa specific engine oil capacity, $1 \mathrm{~kW}^{-1}$

$C_{\mathrm{E}} \quad$ engine oil capacity, 1

ERP engine rated power, $\mathrm{kW}$.

Likewise, the Specific Total Oil Capacity (STOCa) was calculated using the total oil capacity (engine plus transmission, plus hydraulic oil capacities) (Eq. 2):

$$
\text { SEOC } a=\frac{C_{E}+C_{T}+C_{H}}{E R P}, \frac{1}{\mathrm{~kW}}
$$

Where:

STOCa specific total oil capacity, $1 \mathrm{~kW}^{-1}$

$C_{\mathrm{E}} \quad$ engine oil capacity, 1

$C_{\mathrm{T}} \quad$ transmission oil capacity, 1

$C_{\mathrm{H}} \quad$ hydraulic oil capacity, 1

ERP engine rated power, $\mathrm{kW}$.

The Engine Oil Consumption (EOCo) was the engine oil consumption per 100 hours of machine work (Eq. 3):

Where:

$$
\text { EOCo }=\frac{C_{E}}{C I_{E}} \times 100, \frac{1}{100 \mathrm{~h}}
$$

EOCo manufacturer's stated engine oil consumption every 100 hours of machine work, $110^{-2} \mathrm{~h}^{-1}$

$C_{\mathrm{E}} \quad$ engine oil capacity, 1

$C I_{\mathrm{E}} \quad$ change interval of engine oil, $\mathrm{h}$.

The Total Oil consumption (TOCo) was calculated as the total litres of the oil used (engine, transmission and hydraulic systems) per 100 hours of machine work (Eq. 4):

Where:

$$
\text { TOCo }=\left(\frac{C_{E}}{C I_{E}}+\frac{C_{T}}{C I_{T}}+\frac{C_{H}}{C I_{H}}\right) \times 100, \frac{1}{100 \mathrm{~h}}
$$

TOCo manufacturer's stated total oil consumption every 100 hours of machine work, $110^{-2} \mathrm{~h}^{-1}$

$C_{\mathrm{E}} \quad$ engine oil capacity, 1

$\mathrm{CI}_{\mathrm{E}} \quad$ change interval of the engine oil, $\mathrm{h}$

$C_{\mathrm{T}} \quad$ transmission oil capacity, 1

$\mathrm{CI}_{\mathrm{T}} \quad$ change interval of the transmission oil, $\mathrm{h}$

$C_{\mathrm{H}} \quad$ hydraulic oil capacity, 1

$\mathrm{CI}_{\mathrm{H}} \quad$ change interval of the hydraulic oil, $\mathrm{h}$. 
The Specific Engine Oil Consumption (SEOCo) was calculated as the litres of EOCo per unit of $E R P$ (Eq. 5):

Where:

$$
S E O C o=\frac{E O C o}{E R P}, \frac{1}{100 \mathrm{~h} \times \mathrm{kW}}
$$

SEOCo specific engine oil consumption, $110^{-2} \mathrm{~h}^{-1} \mathrm{~kW}^{-1}$

EOCo manufacturer's stated engine oil consumption every 100 hours of machine work, $110^{-2} \mathrm{~h}^{-1}$

ERP engine rated power, $\mathrm{kW}$.

The Specific Total Oil consumption (STOCo) was calculated as the litres of TOCo per unit of ERP (Eq. 6).

$$
\text { STOCo }=\frac{\text { TOCo }}{E R P}, \frac{1}{100 \mathrm{~h} \times \mathrm{kW}}
$$

Where:

STOCo specific total oil consumption, $110^{-2} \mathrm{~h}^{-1} \mathrm{~kW}^{-1}$

TOCo manufacturer's stated total oil consumption every 100 hours of machine work, $110^{-2} \mathrm{~h}^{-1}$

ERP engine rated power, $\mathrm{kW}$.

Further, the absolute difference between the engine oil consumption as indicated by the manufacturer $(E O C o)$ and the predicted engine oil consumption obtained by the equation used in this study (PEOCo) were analysed (Eq. 7), as well as the standardised residuals:

$$
\Delta_{\text {EOCo, } P E O C o}=|E O C o-P E O C o|, \frac{1}{100 \mathrm{~h}}
$$

Where:

$\triangle_{E O C_{0}, P E O C_{0}}$ absolute difference between the manufacturer's stated engine oil consumption and the predicted engine oil consumption, $110^{-2} \mathrm{~h}^{-1}$

EOCo manufacturer's stated engine oil consumption every 100 hours of machine work, $110^{-2} \mathrm{~h}^{-1}$

PEOCo predicted engine oil consumption obtained by this study, $110^{-2} \mathrm{~h}^{-1}$.

The same was done for the total oil consumption (the absolute difference between the total oil consumption indicated by the manufacturer (TOCo) and the predicted total oil consumption using the equation PTOCo) (Eq. 8), along with the standardised residuals:

Where:

$$
\Delta_{\text {TOCo }, \text { PTOCo }}=\mid \text { TOCo }- \text { PTOCo } \mid, \frac{1}{100 \mathrm{~h}}
$$

$D_{\text {TOС }, \text { Pтосо }}$ absolute difference between the manufacturer's stated total oil consumption and the predicted total oil consumption, $110^{-2} \mathrm{~h}^{-1}$

TOCo manufacturer's stated total oil consumption every 100 hours of machine work, $110^{-2} \mathrm{~h}^{-1}$

PTOCo predicted total oil consumption obtained by this study, $110^{-2} \mathrm{~h}^{-1}$.

\subsection{Data Elaboration}

Data were analysed using IBM SPSS Statistics (version 25, International Business Machines Corporation, Armonk, New York, U.S.A.). The dependent variables, used to find the statistical relationship with the rated engine power $(E R P)$, were engine oil consumption (EOCo) and total oil consumption (TOCo) per 100 hours of tractor use. Pearsons correlation was first checked ( $p$-value $<0.01$ ), and subsequently a possible linear regression was investigated, using both the ANOVA and the standardised residual results. In model building, a residual is the difference between the observed and the predicted model values. The standardised residuals (obtained by dividing each residual by the sample standard deviation) provides information as to what extent the observed value is lower or higher than the predicted one and whether the residual is larger than most of the absolute values (Graybill 1961).

The bootstrap method was then used for estimating confidence intervals around regression coefficients, with a nonparametric approach to effect size estimation and hypothesis testing, making no assumptions about the shape of the distributions of the variables (Efron 1979). The sample of 133 tractors was considered as a population from which we extracted several smaller bootstrap samples, used for calculating the regression parameter and for creating a percentile bootstrap confidence interval of these parameters.

\subsection{Comparison of the Model Obtained in This Study with Those of Other Studies}

The predicted engine oil consumption (litres per 100 hours of work of the engine), using the model obtained in this study (PEOCo), was compared with the analogous of Calcante et al. (2017) (CEOCo) and of the ASABE Standard D497.7, clause 3.4 (AEOCo) (Eqs. 9 and 10):

$$
\Delta_{\text {PEOCo,CEOCo }}=\mid \text { PEOCo }- \text { CEOCo } \mid, \frac{1}{100 \mathrm{~h}}
$$

Where:

$D_{\text {PEOCO, CEOCo }}$ absolute difference between the predicted engine oil consumption of this work and the predicted engine oil consumption of Calcante et al. (2017), $110^{-2} \mathrm{~h}^{-1}$

PEOCo predicted engine oil consumption obtained by this study, $110^{-2} \mathrm{~h}^{-1}$

CEOCo predicted engine oil consumption obtained by Calcante et al. (2017), $110^{-2} \mathrm{~h}^{-1}$.

$$
\Delta_{\text {PEOCo, } A E O C o}=|P E O C o-A E O C o|, \frac{1}{100 \mathrm{~h}}
$$


Table 1 Mean \pm standard deviation $(S D)$ of engine rated power (ERP), tank oil capacities of the engine and transmission plus hydraulic systems and corresponding service intervals per classes of ERP

\begin{tabular}{|c|c|c|c|c|c|c|}
\hline $\begin{array}{c}\text { Classes of } \\
\text { ERP } \\
\text { kW }\end{array}$ & $\mathrm{N}$ & $\begin{array}{c}\text { Engine rated power } \\
\text { ERP } \\
\mathrm{kW}\end{array}$ & $\begin{array}{c}\text { Engine oil capacity } \\
\text { EOCa } \\
\mathrm{I}\end{array}$ & $\begin{array}{c}\text { Engine oil } \\
\text { change } \\
\mathrm{h}\end{array}$ & $\begin{array}{c}\text { Transm/hydr oil capacity } \\
\text { THOCa } \\
\text { I }\end{array}$ & $\begin{array}{c}\text { Transm/hydr oil } \\
\text { change } \\
\mathrm{h}\end{array}$ \\
\hline $\mathbf{2} 90$ & 35 & $77.5 \pm 9.2$ & $10.4 \pm 2.4$ & $488.6 \pm 75.8$ & $61.1 \pm 17.1$ & $1192.9 \pm 180.7$ \\
\hline $90-120$ & 39 & $104.7 \pm 9.2$ & $14.3 \pm 3.5$ & $516.7 \pm 54.2$ & $79.4 \pm 26.7$ & $1179.5 \pm 247.0$ \\
\hline $120-200$ & 38 & $150.0 \pm 21.8$ & $19.2 \pm 4.1$ & $535.5 \pm 83.8$ & $120.1 \pm 56.4$ & $1293.4 \pm 313.0$ \\
\hline$>200$ & 21 & $262.1 \pm 60.0$ & $30.2 \pm 8.3$ & $485.7 \pm 65.5$ & $201.9 \pm 61.7$ & $1504.8 \pm 149.9$ \\
\hline
\end{tabular}

Where:

$D_{\text {PEOCo, AEOCo }}$ absolute difference between the predicted engine oil consumption of this work and the predicted engine oil consumption of the ASABE Standard D497.7 (2011), $110^{-2} \mathrm{~h}^{-1}$

PEOCo predicted engine oil consumption obtained by this study, $110^{-2} \mathrm{~h}^{-1}$

AEOCo predicted engine oil consumption obtained by the ASABE Standard D497.7 (2011), $110^{-2} \mathrm{~h}^{-1}$.

We then compared the total oil consumption between the model of this study (PTOCo) and that of Calcante et al. (2019) (Eq. 11):

$$
\Delta_{\text {PTOCo }, \text { СTOCo }}=\mid \text { PTOCo }- \text { CTOCo } \mid, \frac{1}{100 \mathrm{~h}}
$$

Where:

$D_{\text {Pтосо , стосо }}$ absolute difference between the predicted total oil consumption of this work and the predicted total oil consumption in Calcante et al. (2019), $110^{-2} \mathrm{~h}^{-1}$

PTOCo predicted total oil consumption obtained by this study, $110^{-2} \mathrm{~h}^{-1}$

CTOCo predicted total oil consumption obtained by Calcante et al. (2019), $110^{-2} \mathrm{~h}^{-1}$.

\section{Results}

\subsection{Preliminary Information}

The results for engine rated power, oil capacities of the engine and transmission plus hydraulic systems, as well as those for the recommended oil service intervals, were grouped into four engine rated power classes (<90 kW, 90-120 kW, 120-200 kW and >200 kW, Table 1).

Engine rated power $(E R P)$ ranged from 58.8 to $455.9 \mathrm{~kW}$, with an average value of $135.3 \mathrm{~kW}$ and a median of $113.2 \mathrm{~kW}$, confirming a higher percentage of the examined tractors at around $120 \mathrm{~kW}$. The oil capacity of the engine (EOCa) had an average value of $17.2( \pm 7.9) 1 ; 105.6( \pm 63.3) 1$ was the average oil capacity of the transmission and hydraulic systems (THOCa). Both values increased at the highest powers (Table 1).

The recommended engine oil change ranged from 300 to $750 \mathrm{~h}$, with an average value of $509.8( \pm 73.2) \mathrm{h}$ and an average of around $500 \mathrm{~h}$ in all ERP classes (Table 1).

The oil change of the transmission plus hydraulic systems ranged from 750 to $2000 \mathrm{~h}$, with an average value of $1266.9( \pm 264.1) \mathrm{h}$, being around $1200 \mathrm{~h}$ in the first three ERP classes. Only in the highest class $(E R P>200 \mathrm{~kW})$, it increased to about $1500 \mathrm{~h}$ (Table 1).

Person's correlation coefficient of the engine oil capacity $(E O C a)$ with the engine rated power (ERP) was $r=0.86(p<0.01)$. Linear regression analysis produced Eq. 12 (PEOCa, Fig. 1 (left)):

$$
\text { PEOC } a=0.102 E R P+3.434
$$

Where:

PEOCa predicted engine oil capacity, 1

ERP engine rated power, $\mathrm{kW}$.

The variables THOCa and ERP showed a Pearson coefficient equal to $0.75(p<0.01)$, and the linear regression curve PTHOCa was obtained (Eq. 13 and Fig. 1 (right)):

$$
\text { PTHOCa }=0.707 \text { ERP }+9.811
$$

Where:

PTHOCa predicted transmission and hydraulic oil capacity, 1

ERP engine rated power, $\mathrm{kW}$.

Hereafter, we used the variables: engine oil capacity $(E O C a)$ and total oil capacity (TOCa, including engine, transmission and hydraulic systems), as well as EOCo (engine oil consumption) and TOCo (total oil 

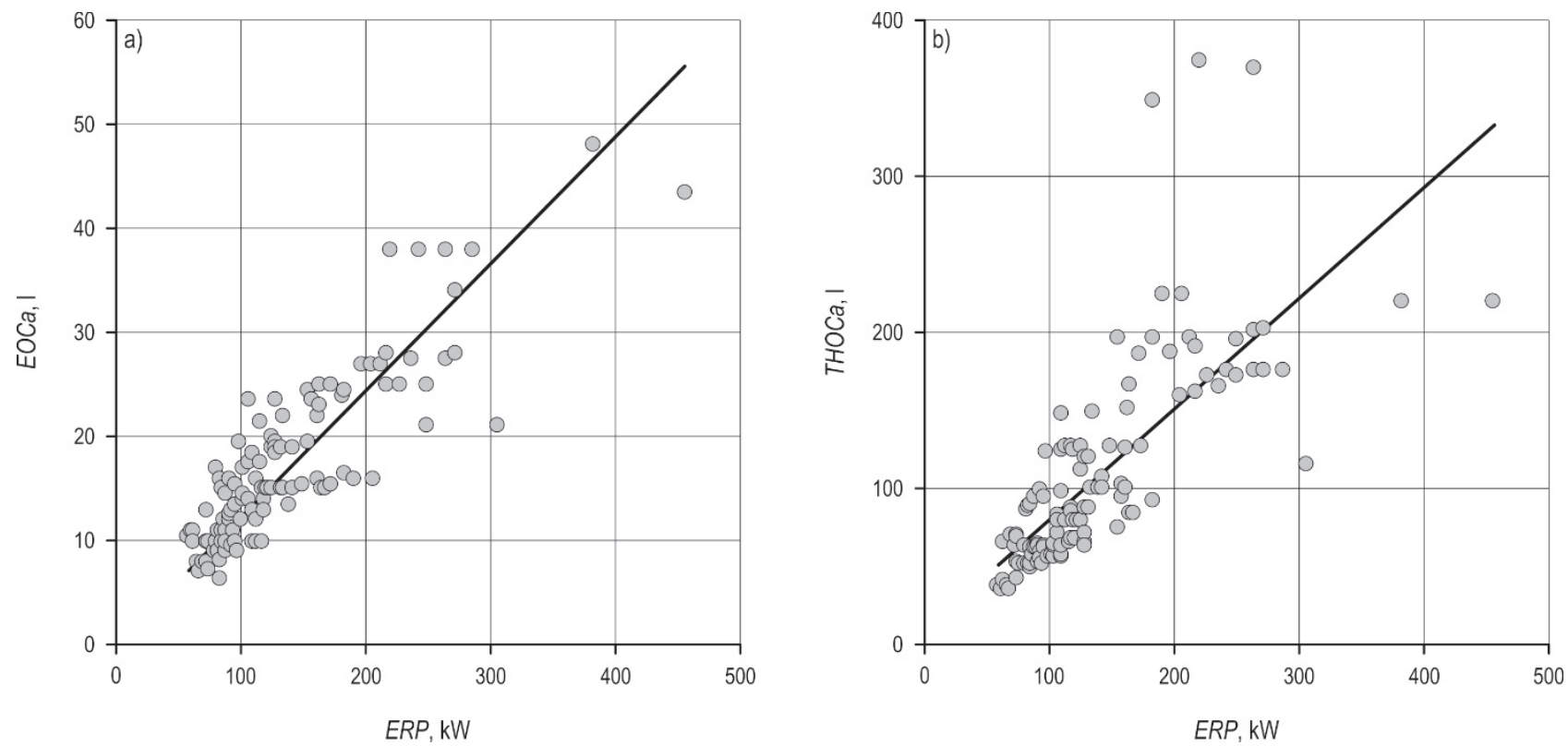

Fig. 1 Relationship between engine rated power (ERP) and a) engine oil capacity (EOCa) and b) transmission plus hydraulic systems oil capacity (THOCa) and corresponding regression curves (PEOCa and PTHOCa)

Table 2 Engine oil consumption (EOCO) and total oil consumption (TOCO) every 100 hours of machine use and their ratios per classes of $E R P$

\begin{tabular}{|c|c|c|c|c|c|}
\hline $\begin{array}{c}\text { ERP } \\
\mathrm{kW}\end{array}$ & \multicolumn{2}{|c|}{$\begin{array}{r}\text { Engine oil consumption } \\
\text { EOCo, } 10^{-2} \mathrm{l} \mathrm{h}^{-1}\end{array}$} & \multicolumn{2}{|c|}{\begin{tabular}{r}
\multicolumn{2}{|c|}{ Total oil consumption } \\
TOCo $10^{-2} \mathrm{~h}^{-1}$
\end{tabular}} & EOCo/TOCo \\
\hline Class & Mean & $S D$ & Mean & SD & $\%$ \\
\hline$<90$ & 2.0 & 0.3 & 7.4 & 1.3 & 26.9 \\
\hline $90-120$ & 2.7 & 0.6 & 9.4 & 1.8 & 28.8 \\
\hline $120-200$ & 3.7 & 0.9 & 13.1 & 3.2 & 28.2 \\
\hline$>200$ & 6.7 & 1.7 & 19.3 & 2.7 & 34.7 \\
\hline
\end{tabular}

consumption, including engine, transmission and hydraulic systems).

The average value of the total oil capacity TOCa was $122.7( \pm 69.2) \mathrm{l}$, and the incidence of EOCa on TOCa ranged from 6.4 to $26.3 \%$, with an average value of 15.2 $( \pm 4.7) \%$.

Mean engine oil consumption EOCo was $3.4( \pm 1.8)$ $10^{-2} 1 \mathrm{~h}^{-1}$, with an average increase from 2 to $6.710^{-2} 1 \mathrm{~h}^{-1}$ in the highest power class (Table 2). Mean total oil consumption TOCo was $11.4( \pm 4.6) 10^{-2} \mathrm{lh}^{-1}$, with an average increase from 7.4 to $19.310^{-2} \mathrm{lh}^{-1}$ in the highest $E R P$. The incidence of EOCo on TOCo ranged from 12.6 to $55.0 \%$, with an average value of $30.1( \pm 9.0 \%)$. Total oil consumption was higher every 100 hours of machine

Table 3 Specific engine oil capacity (SEOCa), specific total oil capacity (STOCa), specific engine oil consumption (SEOCo) and specific total oil consumption (STOCO)

\begin{tabular}{|c|c|c|c|c|}
\hline $\begin{array}{c}\text { ERP } \\
\mathrm{kW}\end{array}$ & $\begin{array}{c}\text { Specific engine oil capacity } \\
\text { SEOCa } \\
\mid \mathrm{kW}^{-1}\end{array}$ & $\begin{array}{c}\text { Specific total oil capacity } \\
\text { STOCa } \\
\mid \mathrm{kW}^{-1}\end{array}$ & $\begin{array}{c}\text { Specific engine oil consumption } \\
\text { SEOCo } \\
10^{-2} \mid \mathrm{kW}^{-1}\end{array}$ & $\begin{array}{c}\text { Specific total oil consumption } \\
\text { STOCo } \\
10^{-2} \mid \mathrm{kW}^{-1}\end{array}$ \\
\hline Class & Mean $\pm S D$ & Mean $\pm S D$ & Mean $\pm S D$ & Mean $\pm S D$ \\
\hline$<90$ & $0.135 \pm 0.031$ & $0.920 \pm 0.172$ & $0.029 \pm 0.011$ & $0.097 \pm 0.015$ \\
\hline $90-120$ & $0.137 \pm 0.032$ & $0.891 \pm 0.220$ & $0.027 \pm 0.006$ & $0.094 \pm 0.021$ \\
\hline $120-200$ & $0.130 \pm 0.028$ & $0.916 \pm 0.293$ & $0.025 \pm 0.007$ & $0.089 \pm 0.025$ \\
\hline$>200$ & $0.116 \pm 0.027$ & $0.917 \pm 0.307$ & $0.024 \pm 0.006$ & $0.082 \pm 0.030$ \\
\hline
\end{tabular}


Table 4 Coefficients of regression line PEOCO

\begin{tabular}{|c|c|c|c|c|c|c|}
\hline \multirow{2}{*}{ Model } & B & Bootstrap ${ }^{\mathrm{a}}$ & \multicolumn{3}{|c|}{$95 \%$ confidence interval } \\
\hline Constant & 0.1082 & -0.00038 & 0.00695 & 0.08262 & -0.066 & \multicolumn{2}{|c|}{ Sign. } & \multicolumn{2}{|c|}{ Lower limit } & 0.183 \\
\hline ERP, $\mathrm{kW}$ & 0.02453 & 0.00001 & 0.00103 & 0.001 & 0.02161 & 0.0277 \\
\hline
\end{tabular}

a -1000 bootstrap samples

work compared to the engine oil consumption $(30 \%$ lower), with the exception of the highest power class $(E R P>200 \mathrm{~kW})$, where it achieved 34.7\% (Table 2).

Mean specific engine oil capacity SEOCa was 0.131 $( \pm 0.30) 1 \mathrm{~kW}^{-1}$ (Table 3$)$, decreasing in the highest power class $(>200 \mathrm{~kW})$ to $0.1161 \mathrm{~kW}^{-1}$. Mean specific total oil capacity STOCa was $0.910( \pm 0.245) 1 \mathrm{~kW}^{-1}$ (almost 1 l, $\mathrm{kW}^{-1}$ Table 3), being about seven times greater than the specific engine oil capacity.

Mean specific engine oil consumption was 0.026 $( \pm 0.008) 10^{-2} 1 \mathrm{~kW}^{-1}$, slightly increasing from the highest to the lowest power classes (from 0.024 to $\left.0.02910^{-2} 1 \mathrm{~kW}^{-1}\right)$. Mean specific total oil consumption was $0.092( \pm 0.023) 10^{-2} 1 \mathrm{~kW}^{-1}$, increasing from 0.082 to $0.09710^{-2} 1 \mathrm{~kW}^{-1}$ from the highest to the lowest ERP classes (Table 3). Specific total oil consumption was more than three times higher than the specific engine oil consumption.

\subsection{Analysis of Oil Consumption as a Function of Engine Rated Power}

Pearson's correlation coefficient between EOCo and ERP was $0.933(p<0.01)$. The model PEOCo, applying the linear regression (Eq. 14), is plotted in Fig. 2 (with the original data EOCo and the $95 \%$ confidence interval, Table 4). The ANOVA validated the obtained linear coefficients $(F=727.833$, Sig $=0.000)$.

$$
\text { PEOCo }=0.02453 E R P+0.10820
$$

Where:

PEOCo predicted engine oil consumption, $10^{-2} 1 \mathrm{~h}^{-1}$ $E R P$ engine rated power, $\mathrm{kW}$.

The bootstrap confidence interval shows the confidence interval for both the constant and the slope variables (Table 4), with a high significance in the slope and a slightly lower significance in the constant (corresponding to a higher standard error).

Although there were four tractors (different models of the same manufacturer) with the same engine

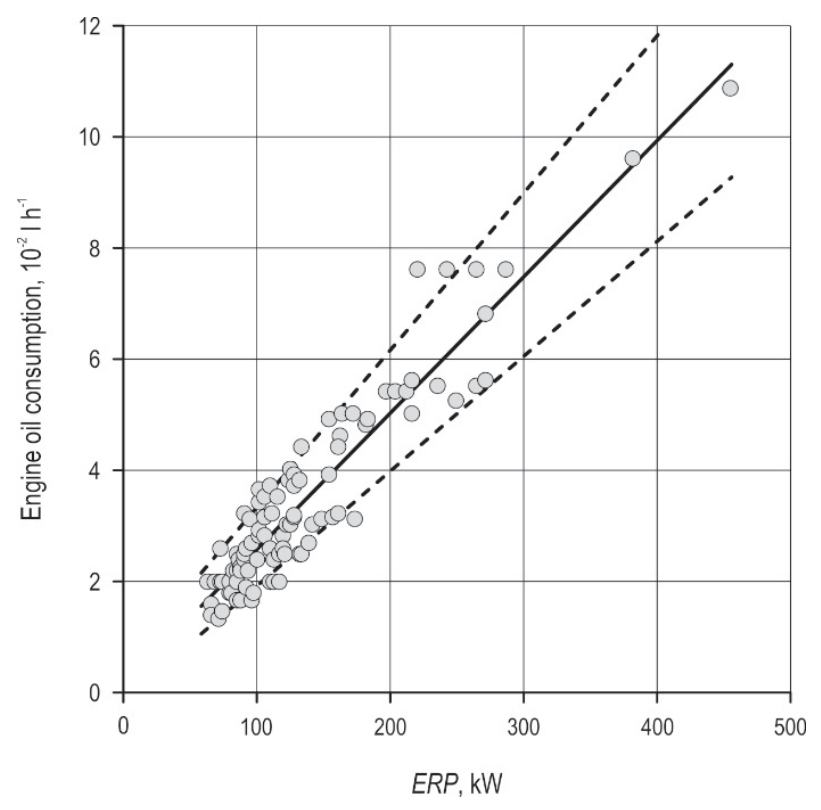

Fig. 2 Plot of engine oil consumption every 100 hours of machine work $\left(10^{-2} \mid \mathrm{h}^{-1}\right)$ as a function of engine rated power ERP $(\mathrm{kW})$, regression line PEOCo and 95\% confidence interval

oil consumption, but with different ERP values (between 200 and $300 \mathrm{~kW}$ ), the high value of the coefficient of determination confirmed that more than $87 \%$ of the variability in the engine oil consumption could be explained by the ERP. The plot of the standardised residuals in Fig. 3 highlights a good random distribution of errors around the zero value. Standardised residuals were well distributed in the interval $0 \pm 2$ (95\% of the observed values), with the exception of two points between 200 and $300 \mathrm{~kW}$ (as previously observed, Fig. 2). The standardised residuals are a measure of the difference strength between the observed and expected values.

Pearson's correlation coefficient between total oil consumption TOCo and ERP was high $(0.90, p<0.01)$. The model PTOCo (linear regression, Eq. 15) is plotted with the original data TOCo in Fig. 4 and with the 95\% 


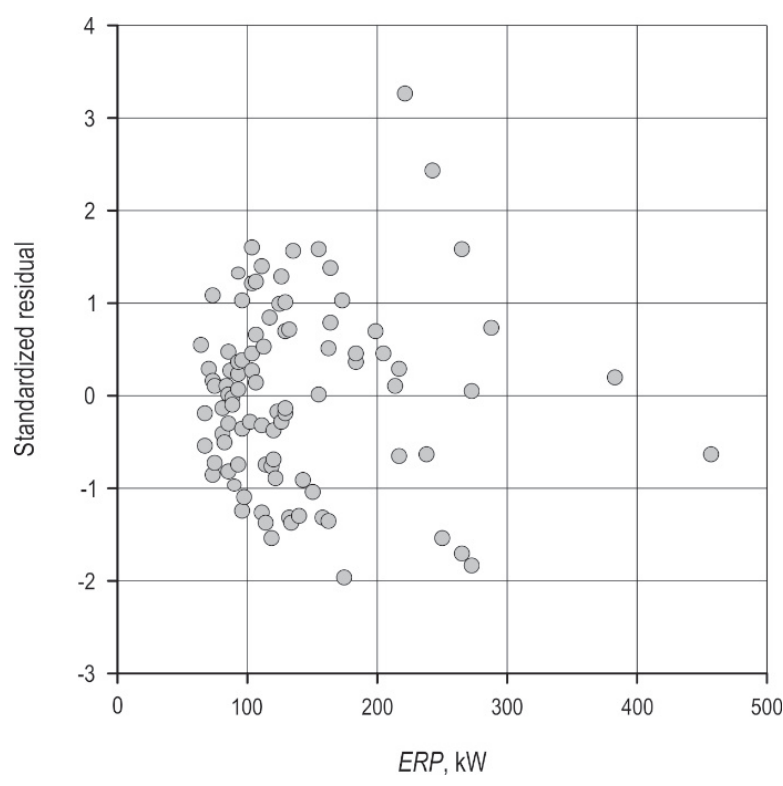

Fig. 3 Plot of standardised residuals of engine oil consumption

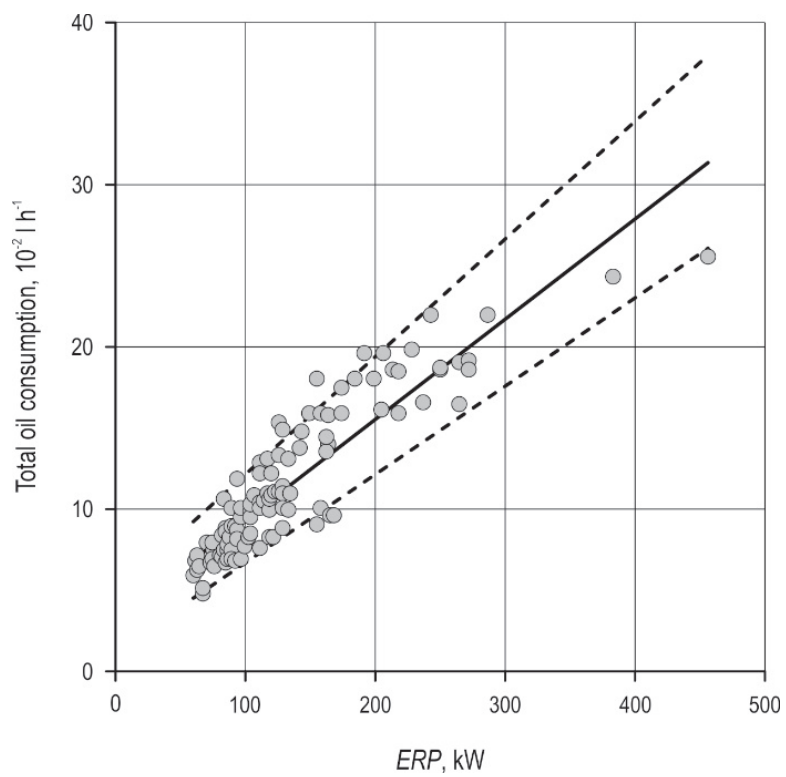

Fig. 4 Plot of total oil consumption every 100 hours of tractor work $\left(10^{-2} \mathrm{I}^{-1}\right)$ as a function of engine rated power ERP $(\mathrm{kW})$, of regression line PTOCo and 95\% confidence interval confidence interval (Table 5). The ANOVA confirmed, also in this case, the goodness of the linear regression values $(F=491.204$, $\operatorname{Sig}=0.000)$ :

$$
\text { PTOCo }=0.06181 E R P+3.12141
$$

Where:

PTOCo predicted total oil consumption, $10^{-2} 1 \mathrm{~h}^{-1}$ ERP engine rated power, $\mathrm{kW}$.

The bootstrap showed a good significance both in the constant and in the slope of the model PTOCo (Table 5).

The coefficient of determination explained $81 \%$ of the estimated total oil consumption as a function of ERP. The plot of the standardised residuals shows some outliers, especially in the middle ERPS, other than the lowest value corresponding to the highest ERP (Fig. 5).

\subsection{Comparison of PEOCo and PTOCo models with other studies}

The PEOCo was compared with the linear models AEOCo of the ASABE Standard D497.7 and the CEOCo of Calcante et al. (2017). It was first necessary to change all the coefficients to obtain the same prevision of oil consumption every 100 hours (Table 6).

The model of engine oil consumption PEOCo gave results just below CEOCo, while AEOCo showed the highest values (Fig. 6). At $74 \mathrm{~kW}$ (the first percentile of the engine rated power ERP), PEOCo was 1.92 $\left(10^{-2} 1 \mathrm{~h}^{-1}\right)$ against $2.76\left(10^{-2} 1 \mathrm{~h}^{-1}\right)$ of CEOCo $(-30.3 \%)$ and $6.54\left(10^{-2} 1 \mathrm{~h}^{-1}\right)$ of AEOCo $(-70.6 \%)$.

The absolute difference between PEOCo and CEOCo decreased when the ERP increased: it decreased from $0.84\left(10^{-2} 1 \mathrm{~h}^{-1}\right)$ at the first percentile of the engine rated power ERP $(74 \mathrm{~kW})$ to $0.81\left(10^{-2} 1 \mathrm{~h}^{-1}\right)$ at the median $(113 \mathrm{~kW})$ and to $0.74\left(10^{-2} 1 \mathrm{~h}^{-1}\right)$ at the highest value $(235 \mathrm{~kW})$.

On the contrary, the absolute difference between AEOCo and PEOCo increased from $4.61\left(10^{-2} 1 \mathrm{~h}^{-1}\right)$ at the first percentile of ERP to $5.96\left(10^{-2} 1 \mathrm{~h}^{-1}\right)$ at the median and to $10.17\left(10^{-2} 1 \mathrm{~h}^{-1}\right)$ at the highest value.

Table 5 Coefficients of regression line PTOCo

\begin{tabular}{|c|c|c|c|c|c|c|}
\hline \multicolumn{3}{|c|}{ Bootstrap $^{\mathrm{a}}$} \\
\hline \multirow{2}{*}{ Model } & $\mathrm{B}$ & Bias & Standard error & \multirow{2}{*}{ Sign. } & \multicolumn{3}{|c|}{$95 \%$ confidence interval } \\
\cline { 5 - 7 } & & & & & Lower limit & Upper limit \\
\hline Constant & 3.12141 & -0.07077 & 0.54682 & 0.001 & 1.3989 & 5.56061 \\
\hline$E R P, \mathrm{~kW}$ & 0.06181 & 0.00055 & 0.00449 & 0.001 & 0.05438 & 0.07242 \\
\hline
\end{tabular}

a -1000 bootstrap samples 


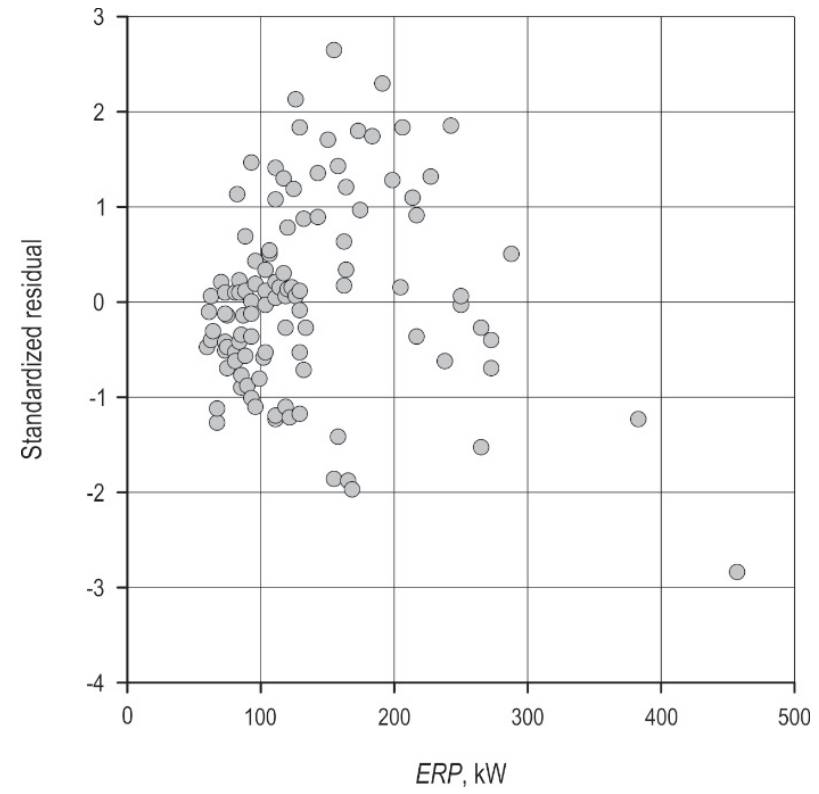

Fig. 5 Plot of standardised residuals of total oil consumption

Table 6 Model of engine and total oil consumption $A E O C O, C E O C$, PEOCo, CTOCo and PTOCo every 100 hours of machine work $\left(10^{-2}\right.$ $\left(\mathrm{h}^{-1}\right)$ as a function of engine rated power ERP

\begin{tabular}{|c|c|c|c|}
\hline \multicolumn{2}{|c|}{ Engine oil consumption, $10^{-2} \mathrm{Ih}^{-1}$} & \multicolumn{2}{c|}{ Total oil consumption, $10^{-2} \mathrm{Ih}^{-1}$} \\
\hline AEOCO $^{1}$ & $0.059 E R P+2.169$ & - & - \\
\hline CEOCO $^{2}$ & $0.0239 E R P+0.989$ & CTOCo $^{3}$ & $0.06178 E R P+4.9855$ \\
\hline PEOCo & $0.0245 E R P+0.1082$ & PTOCo & $0.06181 E R P+3.1214$ \\
\hline
\end{tabular}

Fig. 7 shows the plot of the absolute differences between:

$\Rightarrow$ the predicted engine oil consumption obtained in this work and the engine oil consumption obtained by the manufacturers ( $\mid$ PEOCo-EOCo $\mid$ )

$\Rightarrow$ the predicted engine oil consumption in Calcante et al. (2017) and the engine oil consumption as given by the manufacturers (|CEOcoEOCol)

$\Rightarrow$ the predicted engine oil consumption of the ASABE Standard D497.7 and the engine oil consumption as given by the manufacturers ( $\mid A E O$ Co-EOCo|).

The $|C E O C o-E O C o|$ and $\mid$ PEOCo-EOCo $\mid$ were randomly distributed in the area between 0 and $210^{-2} 1 \mathrm{~h}^{-1}$, independently from ERP (Fig. 7), while $\left|A E O C_{0}-E O C_{0}\right|$ increased as a function of ERP from 5 to $1710^{-2} 1 \mathrm{~h}^{-1}$, with a Pearson's correlation value of $0.964(p<0.01)$.

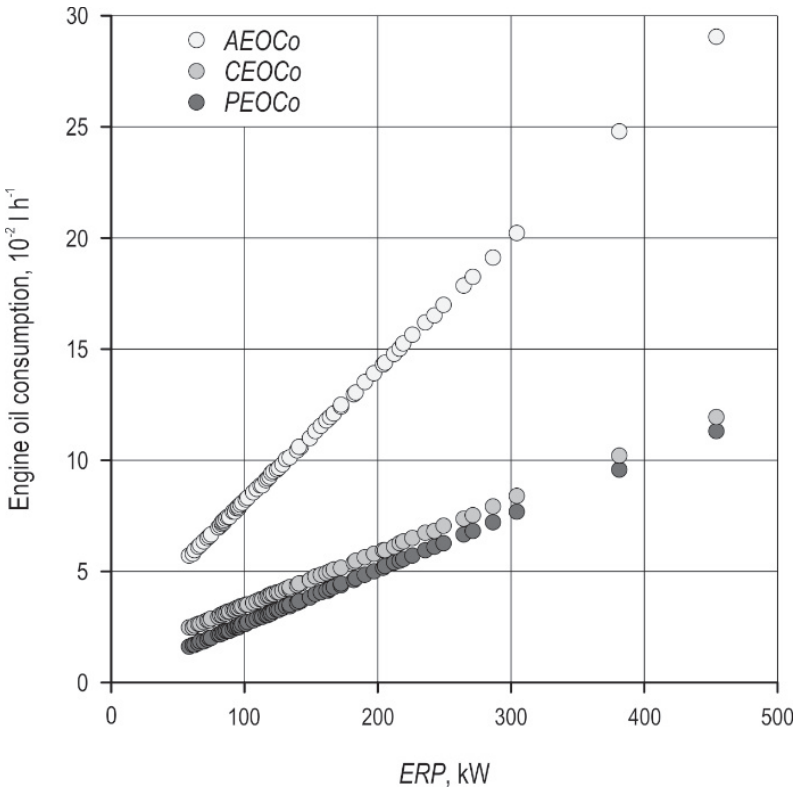

Fig. 6 Different predicted engine oil consumptions $\left(10^{-2} \mathrm{I} \mathrm{h}^{-1}\right)$ : this study (PEOCo, dark grey), ASABE Standard D497.7 (AEOCo, light grey) and Calcante et al. (2017) (CEOCo, medium gray), as a function of engine rated power $E R P(\mathrm{~kW})$

Fig. 8 shows the plots of PTOCo (the model of total oil consumption obtained in this work) and of CTOCo

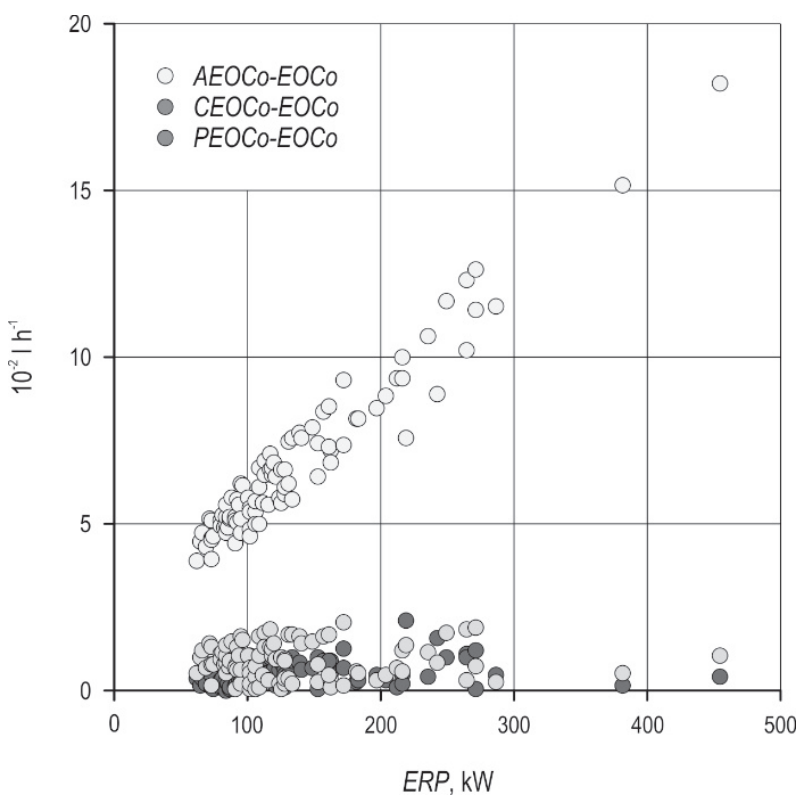

Fig. 7 Plots of absolute differences between manufacturers' engine oil consumption of 133 examined machines EOCo and predicted engine oil consumption of: 1) this study (PEOCo, dark gray); 2) Calcante et al. (CEOCo, medium grey); 3) ASABE Standard D497.7 (AEOCo, light grey) 


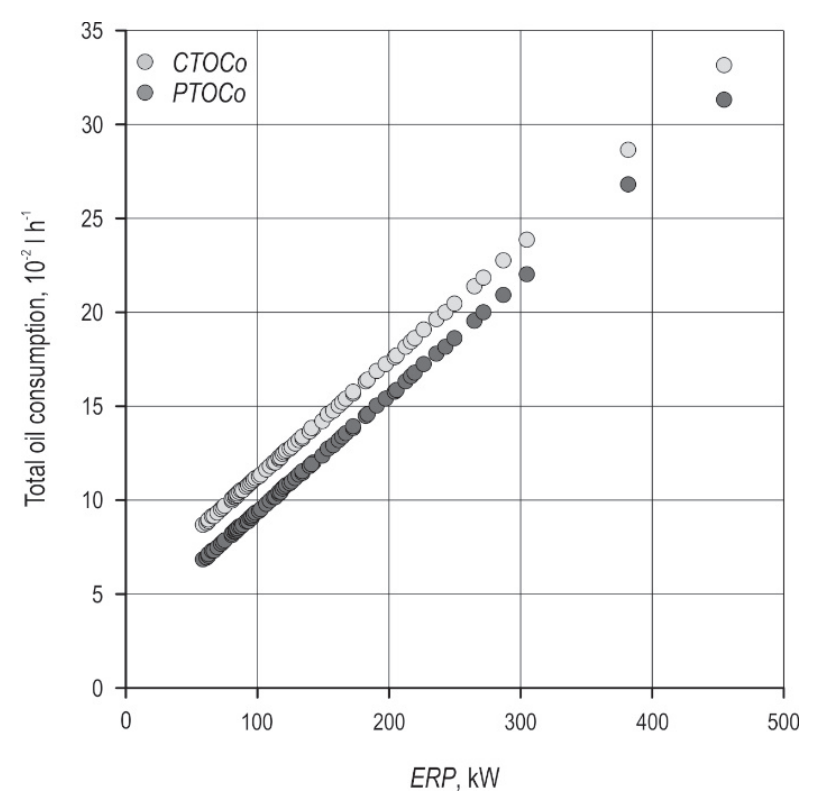

Fig. 8 Plots of the predicted total oil consumption of this study (PTOCo, dark grey) and of Calcante et al. (2019, CTOCo, light grey) every 100 hours of machine work as a function of engine rated power ERP (kW)

(the model of total oil consumption obtained by Calcante et al. in 2019).

\section{Discussion}

Modelling the lubrication oil consumption in a versatile machine, such as a farm tractor used in different forestry operations, with different engine and hydraulic system loads, is complex. It is, however, necessary to have a simple and reliable prediction model to estimate economic and environmental costs of the operations carried out by these machines.

Manufacturers provide indications on the recommended oil change intervals and on the characteristics of the oil, even though the visual inspections are the best method to decide the oil changes (Hofman and Kucera 1987). Some recent studies (Bekana et al. 2015, Sejkorová and Glos 2017) found that the optimal oil change, for good engine performance, mainly depends on the performed tasks and on the oil quality. Recent studies have investigated the characteristics and wear of the oils used in the engine and in the transmission and hydraulic systems of the farm tractors, and new types of oil are now available, complying with the new engine and transmission requirements and with the environmental aspects (Baron et al. 2015, Kosiba et al. 2016, Kučera and Aleš 2017), also extending the intervals in the lubricant oil change. The equation of the ASABE Standard D497.7 for the engine oil consumption considered a service interval of 100 hours, while nowadays the recommended service interval is up to 500-700 hours, depending on the model and manufacturer's recommendations. The lubrication characteristics of oils have also changed in these decades, and oils considered to be of high quality some years ago do not perform well in new engines (Harrison 1992).

In their cost calculation for chipping using a farm tractor, Röser et al. (2011) stated a motor oil consumption of $0.0861 \mathrm{~h}^{-1}$, while with the model of this work (considering an average engine rated power of $163 \mathrm{~kW}$ ), the engine oil consumption was $0.041 \mathrm{l} \mathrm{h}^{-1}$ $\left(0.0481 \mathrm{~h}^{-1}\right.$ with the model of Calcante et al. 2017 , and $0.1181 \mathrm{~h}^{-1}$ with the ASABE Standard D497.7 model). For total oil consumption, Röser et al. (2011) obtained $0.1861 \mathrm{~h}^{-1}\left(0.1321 \mathrm{~h}^{-1}\right.$ in this work and $0.150 \mathrm{in}$ Calcante et al. (2019)).

Concerning the difference between PEOCo and CEOCo models in terms of engine oil consumption, the absolute differences were low, differently from the results in percentage, more dissimilar at the lowest engine rated powers. At the first percentile $(74 \mathrm{~kW})$, the PEOCo was $30 \%$ lower than the CEOCo, 22\% lower at the median $(113 \mathrm{~kW})$ and $11 \%$ lower at the highest percentile $(235 \mathrm{~kW})$. These differences can be explained by the different datasets: specifically, Calcante et al. (2017) investigated a higher number of $2 \mathrm{WD}$ tractors with lower ERPs.

The PEOCo was $71 \%$ lower than the AEOCo (the ASABE Standard model) at the lowest ERP percentile, $67 \%$ lower at the median and $63 \%$ lower at the highest value, with a non-significant decrease, confirming the overestimation of the ASABE model in terms of engine oil consumption.

The predicted total oil consumption of Calcante et al. (2019) was close to the total oil consumption of this work regarding the $P T O C o$, and the mean difference between the two models was 18\%, being highest (25\%) at the first $E R P$ percentile $(74 \mathrm{~kW})$ and decreasing to $18 \%$ at the median $(113 \mathrm{~kW})$ and to $8 \%$ at the highest percentile (235 kW). Although Calcante et al. (2019) analysed a dataset of farm tractors with different characteristics (2WD, 4WD and crawler), the models are relatively similar.

Reliable models for lubricant oil consumption in agricultural and forestry tractors may be useful both at an economic and environmental level: the former for predicting a more precise mechanisation cost, the latter for a best compliance in the environmental analysis (Đuka et al. 2017, Berg 1997). 


\section{Conclusions}

Despite a wide variability in the capacity of the oil pans and oil service intervals (as a function of tractor characteristics and manufacturers' choices), this study showed a good correlation between the engine rated power with both the engine and the total oil consumption in 4WD farm tractors used in forest operations. For engine oil consumption, the results were similar to those obtained in 2017 by other authors, confirming the necessity of a revision of the ASABE Standard model. This Standard uses the same equation as used in the 1980s, when oil change was focused on short changing intervals (usually 100 hours) and high specific oil pan capacity, requiring a great amount of oil. At that time, tractors were equipped with simple range and gear transmissions: the hydraulic system consisted of the three-point linkage and some hydraulic hitches. The control of the oil level in the transmission and hydraulic systems was the only concern of the operators, and the oil was only changed when important maintenances occurred. Nowadays, the widespread application of semi and full-power-shift and continuous variable transmissions and the high number of hydraulic hitches (important features for the equipment in forestry tasks) increase the amount of oil required for the transmission and hydraulic systems. The model obtained in this work was similar to those studied by other authors in 2019, with slight differences due to the different types of examined farm tractors, confirming that a new approach is necessary when considering the lubrication analysis in these machines.

\section{References}

Ackerman, P., Williams, C., Ackerman, S., Nati, C., 2017: Diesel Consumption and Carbon Balance in South African Pine Clear-Felling CTL Operations: a Preliminary Case Study. Croatian Journal of Forest Engineering 38(1): 65-72.

Afsharnia, F., Asoodar, M.A., Abdeshahi, A., Marzban, A., 2015: Repair and Maintenance Capability and Facilities Availability for MF 285 Tractor Operators in North of Khouzestan Province. International Journal of Mechanical, Aerospace, Industrial, Mechatronic and Manufacturing Engineering 9(6): 1153-1156.

Athanassiadis, D., Lidestav, G., Wästerlund, I., 1999: Fuel, hydraulic oil and lubricant consumption in Swedish mechanized harvesting operations. Journal of Forest Engineering 10(1): 59-66.

ASAE Standards D230.4, 1984: Agricultural Machinery Management Data. St. Joseph, Mich: ASAE.

ASAE Standards EP391.1, 1984: Agricultural Machinery Management. St. Joseph, Mich.: ASAE.
ASAE Standards D497.4, 1999: Agricultural Machinery Management Data. St. Joseph, Mich.: ASAE.

ASAE Standards EP496.2, 1999: Agricultural Machinery Management. St. Joseph, Mich.: ASAE.

ASABE Standards D497.7, 2011 Rev. 2015: Agricultural Machinery Management Data. St. Joseph, Mich.: ASABE.

ASABE Standards. EP496.3, 2006: Agricultural Machinery Management. St. Joseph, Mich.: ASABE.

Baron, P., Kočiško, M., Dobránsky, J., Pollák, M., Cmorej, T., 2015: Research and correlation of diagnostic methods for assessment of the state of oil filling in cycloid gearbox. Advances in Materials Science and Engineering 24: 1-9. http:// dx.doi.org/10.1155/2015/597841

Bekana, D., Antoniev, A., Zach, M., Mareček, J., 2015: Monitoring of agricultural machines with used engine oil analysis. Acta Universitatis Agriculturae Et Silviculturae Mendelianae Brunensis 63(1): 15-22. https://doi.org/10.11118/actaun201563010015

Berg, S., 1997: Some aspects of LCA in the analysis of forestry operations. Journal of Cleaner Production 5(3): 211-217. https://doi.org/10.1016/S0959-6526(97)00040-1

Beuk, D., Tomašić, Ž., Horvat, D., 2007: Status and development of forest harvesting mechanisation in Croatian state forestry. Croatian Journal of Forest Engineering 28(1): 63-82.

Bright, G., 2004: Calculating costs and charges for forest machinery use. Forestry 77(2): 75-84. https://doi.org/10.1093/ forestry/77.2.75

Buckmaster, D.R., 2003: Benchmarking tractor costs. Applied Engineering in Agriculture 19(2): 151-154.

Calcante, A., Brambilla, M., Bisaglia, C., Oberti, R., 2017: Proposal to estimate the engine oil consumption in agricultural tractors. Applied Engineering in Agriculture 33(2): 191-194. https://doi.org/10.13031/aea.11992

Calcante, A., Brambilla, M., Bisaglia, C., Oberti, R., 2019: Estimating The Total Lubricant Oil Consumption Rate In Agricultural Tractors. Transactions of the ASABE 62(1): 197-204. https://doi.org/10.13031/trans.12803

Dahab, M.H., Kheiry, A.N.O., Talha, T.H.A., 2016: A Computer Model of Fuel Consumption Estimation for Different Agricultural Farm operations. International Journal of Environmental \& Agriculture Research 2(3): 77-85.

Đuka, A., Vusić, D., Horvat, D., Šušnjar, M., Pandur, Z., Papa, I., 2017: LCA studies in forestry - stagnation or progress? Croatian Journal of Forest Engineering 38(2): 311-326.

Efron, B., 1979: Bootstrap Methods: Another Look at the Jackknife. Annals of Statistics 7(1): 1-26.

Fairbanks, G.E., Larson, G.H., Chung, D.S., 1971: Cost of using farm machinery. Transaction of ASAE 14(1): 98-101. https://doi.org/10.13031/2013.38233

Gilanipoor, N., Najafi, A., Heshmat Alvaezin, S.M., 2012: Productivity and cost of farm tractor skidding. Journal of Forest Science 58(1): 21-26. https://doi.org/10.17221/4804-JFS 
Graybill, F.A., 1961: An Introduction to Linear Statistical Models. Volume I. $1^{\text {st }}$ ed., McGraw Hill: New York-TorontoLondon, 1-463. https://doi.org/10.1002/bimj.19610030412

Grisso, R.D., Kocher, M.F., Vaughan, D.H., 2004: Predicting Tractor Fuel Consumption. Applied Engineering in Agriculture.20(5):553-561.https://doi.org/10.13031/2013.17455)@2004

Grisso, R.D., Vaughan, D.H., Roberson, G.T., 2008: Fuel prediction for specific tractor models. Applied Engineering in Agriculture 24(4): 423-428. https://doi.org/10.13031/2013.25139

Grisso, R., Pitman, R., 2014: Five Strategies for Extending Machinery Life. Virginia Cooperative Extension Publication, 442-451.

Guerrieri, M., Fedrizzi, M., Antonucci, F., Pallottino, F., Sperandio, G., Pagano, M., Figorilli, S., Menesatti, P., Costa, C., 2016: An innovative multivariate tool for fuel consumption and costs estimation of agricultural operations. Spanish Journal of Agricultural Research 14(4): 1-11. https://doi. org/10.5424/sjar/2016144-9490

Hawkins, E.M., Buckmaster, D.R., 2015: Benchmarking Costs Of Fixed-Frame, Articulated, and Tracked Tractors. Applied Engineering in Agriculture 31(5): 741-745. https://doi. org/10.13031/aea.31.11074

Harrison, D.S., 1992: Farm Tractor and Equipment Maintenance. Fact Sheet EES-47. Florida Cooperative Extension Service, Institute of Food and Agricultural Sciences, University of Florida.

Hofman, V.L., Kucera, H.L., 1987: Extend machinery life to save dollars. Cooperative Extension Service AE 929 North Dakota State University, Fargo.

Hunt, D.R., 1974: Eight Years of Farm Machinery Cost Monitoring. ASAE Paper No 741544. St Joseph Mich.

Khodabakhshian, R., 2013: A review of maintenance management of tractors and agricultural machinery: preventive maintenance systems. Agricultural Engineering International: CIGR Journal 15(4): 147-159.

Klvač, R., Skoupý, A., 2009: Characteristic fuel consumption and exhaust emissions in fully mechanized logging operations. Journal of Forest Research 14(6): 328-334. https://doi. org/10.1007/s10310-009-0143-7

Kosiba, J., Čorňák, Š., Glos, J., Jablonický, J., Vozárová, V., Petrović, A., Csillag, J., 2016: Monitoring oil degradation during operating tests. Agronomy Research 14(5): 1626-1634.

Kučera, M., Aleš, Z., 2017: Morphology Analysis of Friction Particles Generated in Tractor Transmission Oils. Acta Technologica Agriculturae 20(3): 57-62. https://doi.org/10.1515/ ata-2017-0012

Marchi, E., Picchio, R., Spinelli, R., Verani, S., Venanzi, R., Certini, G., 2014: Environmental impact assessment of different logging methods in pine forests thinning. Ecological Engineering 70: 429-436. https://doi.org/10.1016/j.ecoleng.2014.06.019

Molari, G., Molari, P.G., Pagliarani, S., Sedoni, E., 2008: Evaluation of oil flows for the lubrication of an agricultural tractor transmission. Trans. ASABE 51(3): 791-796. https://doi. org/10.13031/2013.24516

Nordfjell, T., Björheden, R., Thor, M., Wästerlund, I., 2010: Changes in technical performance, mechanical availability and prices of machines used in forest operations in Sweden from 1985 to 2010. Scandinavian Journal of Forest Research 25(4): 382-389. http://dx.doi.org/10.1080/02827581.2010.4983 85

Röser, D., Sikanen, L., Asikainen, A., Parikka, H., Väätäinen, K., 2011: Productivity and cost of mechanized energy wood harvesting in Northern Scotland Biomass and Bioenergy 35(11): 4570-4580. https://doi.org/10.1016/j.biombioe.2011.06.028

Sejkorová, M., Glos, J., 2017: Analysis Of Degradation Of Motor Oils Used In Zetor Tractors. Acta Universitatis Agriculturae Et Silviculturae Mendelianae Brunensis 65(1): 179-187. https://doi.org/10.11118/actaun201765010179

Siemens, J.C., Bowers, W., 1999: Machinery management: How to select machinery to fit the real needs of farm managers. Farm Business Management (FBM) series, John Deere Publishing, East Moline, IL. Iowa USA.

Skrobacki, A., 1989: A simulation model on fuel use on a farm. In Land and Water Use, $1^{\text {st }}$ ed.; Dodd, J., Grace, M. Eds.; Balkema, Rotterdam, 4: 2569-2574.

Spinelli, R., Nati, C., Magagnotti, N., 2005: Harvesting and transport of root biomass from fast-growing poplar plantations. Silva Fennica 39(4): 539-548.

Spinelli, R,. Magagnotti, N., 2009: Logging residue bundling at the roadside in mountain operations. Scandinavian Journal of Forest Research 24(2): 173-181. https://doi.org/10.1080/ 02827580902806593

Spinelli, R., Magagnotti, N., Nati, C., 2010: Benchmarking the impact of traditional small-scale logging systems used in Mediterranean forestry. Forest Ecology and Management 260(11): 1997-2001. https://doi.org/10.1016/j.foreco.2010.08.048

Spinelli, R., Magagnotti, N., 2012: Wood extraction with farm tractor and sulky: estimating productivity, cost and energy consumption. Small-scale Forestry 11(1): 73-85. https://doi. org/10.1007/s11842-011-9169-8

Spinelli, R., Magagnotti, N., 2014: Determining long-term chipper usage, productivity and fuel consumption. Biomass and Bioenergy 66: 442-449. https://doi.org/10.1016/j.biombioe.2014.04.016

Srivastava, A.K., Goering, C.E., Rohrbach, R.P., Buckmaster, D.R., 2006: Engineering Principles of Agricultural Machines $2^{\text {nd }}$ ed. S.Joseph, Mich.: 1-559.

Šušnjar, M., Horvat, D., Kristić, A., Pandur, Z., 2008: Morphological analysis of forest tractor assemblies. Croatian Journal of Forest Engineering 29(1): 41-51.

Tolosana, E., Laina, R., Martínez-Ferrari, R., Ambrosio, Y., 2011: Recovering of forest biomass from Spanish hybrid poplar plantations. Biomass and Bioenergy 35(7): 2570-2580. https://doi.org/10.1016/j.biombioe.2011.02.007 
Wahby, M.F., Babeir, A.S., 1994: A study of agricultural tractor service intervals and break-down in some southern farms of Saudi Arabia. Journal of Agricultural Research 39(2): 167-180.

Weber, J.A., 1958: Maintenance Inspection of Sixty farm Tractors. Bulletin 624, Agricultural Experimental Section, University of Illinois.
Wertz, K., Grisso, R., Von Bargen, K., 1990: A survey of agricultural tractor service intervals. Part I. Applied Engineering in Agriculture 6(5): 537-541. https://doi.org/10.13031/ 2013.26424

Witney, B., 1988: Choosing and using farm machines. Longman Scientific and Technical, Singapor,e 1-412.

(C) 2020 by the authors. Submitted for possible open access publication under the terms and conditions of the Creative Commons Attribution (CC BY) license (http://creativecommons.org/licenses/by/4.0/).

Authors' addresses:

Prof. Gianfranco Airoldi, PhD

e-mail: gianfranco.airoldi@unito.it

Prof. Angela Calvo, PhD *

e-mail: angela.calvo@unito.it

Prof. Marco Manzone, PhD

e-mail: marco.manzone@unito.it

University Turin

Department of Agricultural, Forest and Food

Sciences and Technologies

Largo P. Braccini 2

10095 Grugliasco, Turin

ITALY

* Corresponding author 